\title{
OGILVIE SYNDROME FOLLOWING SPINAL SURGERY
}

\author{
Romulo Pedroza Pinheiro, ${ }^{1}$ Nascimento Ribeiro Leonardo, ${ }^{2}$ \\ Tavares Costa Rodrigo Herton, ${ }^{2}$ Aparecido Defino Luiz Helton ${ }^{2}$ \\ ${ }^{1}$ Department of Orthopaedic and Anesthesiology and Doctoral Student, \\ Ribeirão Preto Medical School, University of São Paulo, Brazil \\ ${ }^{2}$ Department of Orthopaedic and Anesthesiology, Ribeirão Preto Medical School, \\ University of São Paulo, Brazil
}

Primljen/Received 26. 09. 2021. god.

Abstract: Objective: Ogilvie syndrome is a rare disease characterized by acute abdominal pain and distention in the absence of mechanical obstruction. It is a rare condition that usually affects hospitalized patients in association with severe illness or after surgery. A few cases have been reported after spinal surgery.

Material and Methods: Retrospective reports of Ogilvie syndrome in three patients that underwent spinal surgery (two posterior lumbar instrumented fusion and one anterior cervical fusion). Surgical treatment was required in two patients and conservative treatment in one out the three patients.

Results: Two patients had a complete recovery of symptoms and signs of the disease, and one died.

Conclusion: Ogilvie syndrome is rare, but it should be considered a differential diagnosis in patients who have undergone surgery and present with significant abdominal pain and distention.

\section{Level of evidence II; Retrospective study.}

Keywords: Ogilvie's syndrome, pseudo-obstruction, spinal fusion.

\section{INTRODUCTION}

Ogilvie syndrome is the eponym to describe a rare condition characterized by acute colonic dilation in the absence of mechanical obstruction colonic (1). Acute colonic pseudo-obstruction (ACPO) was first described by William Heneage Ogilvie in 1948 (2).

The incidence of ACPO is 100 cases per 10000 admissions $(3,4)$. ACPO has been described in hospitalized patients with severe illness, trauma, or after surgical procedures (cesarean, abdominal, pelvic ,urologic , thoracic, neurosurgical, coronary bypass, orthopaedic surgeries) $(1,2,3,5,6)$. ACPO has also been
Prihvaćen/Accepted 06. 11. 2021. god.

described after some orthopedic procedures such as hip, knee, lumbar and cervical surgeries (8-12).

The clinical picture of Ogilvie syndrome includes abdominal distention and pain (80\%), nausea with or without vomiting (60\%) (1). Bowel sounds are preserved in almost $90 \%$ of patients associated with the tympanic abdomen (13). Abdomen radiographs and CT show varying degrees of bowel distention without mechanical obstruction (14). Colonic ischaemia or perforation can occur in $15 \%$ of the patients and is associated with $40 \%$ mortality. Early diagnosis and adequate treatment have a crucial role in the prognosis of $\mathrm{ACPO}(3,15,16)$.

ACPO is an unusual complication following spinal procedures, and it was the motivation to report the occurrence of ACPO during our practice. The goal of the study is to retrospectively report the occurrence, treatment, and results of Ogilvie's syndrome in patients that underwent spinal surgery to highlight the clinical features of ACPO so that it can be considered in the possible postoperative complications of spinal surgery.

\section{MATERIAL AND METHODS}

The study was approved by the local IRB and it is a retrospective report of Ogilvie syndrome in patients that underwent spinal surgery. Three patients presented Ogilvie syndrome after posterior spinal fusion (2 patients) and anterior cervical fusion (1 patient). Two patients were female, and the age of patients ranged from 41 to 83 years $(61.33 \pm 29)$. The detailed clinical picture and procedures are described:

Patient No 1: An 83-year-old female with degenerative scoliosis and lumbar stenosis underwent posterior standalone deformity correction, lumbar 
decompression, and T10-L5 fixation with a pedicle screw-based system. The surgery was uneventful without complications. On the second postoperative day, the patient had increased abdominal distension, abdominal pain, nausea, and vomiting. At the time, abdominal plain radiography showed a dilated cecum and colon (Figure 1). After general surgery consultation, a nasogastric tube was placed as well as medical management, replacement of electrolytes and fluid. On the sixth postoperative day, the patient experienced increased abdominal distension, and neostigmine administration was planned after transfer to the intensive care unit as a result of monitoring requirements, oxygen support, and orotracheal intubation. CT showed dilated bowel of ascending colon without evidence of perforation with suffering from the colon mucosa was observed. (Figure 2). At this time, a decompressive colonoscopy was performed due to abdominal distention. The clinical picture presented partial recovery. The patient died on the 20th postoperative day after worsening of the clinical and respiratory function.

Patient No 2: A 60-year-old female with degenerative lumbar stenosis underwent posterior lumbar decompression and L1-S1 fixation with a pedicle screw-based system. The surgery was uneventful without complications. On the third postoperative day, the patient presented abdominal pain and distention. Abdominal plain radiography and CT showed dilated bowel without evidence of perforation (Figure 3). On the fourth postoperative day, the patient presented worsening of clinical picture associated with nausea, vomiting, and increased abdominal distension. Exploratory laparotomy was performed associated with right

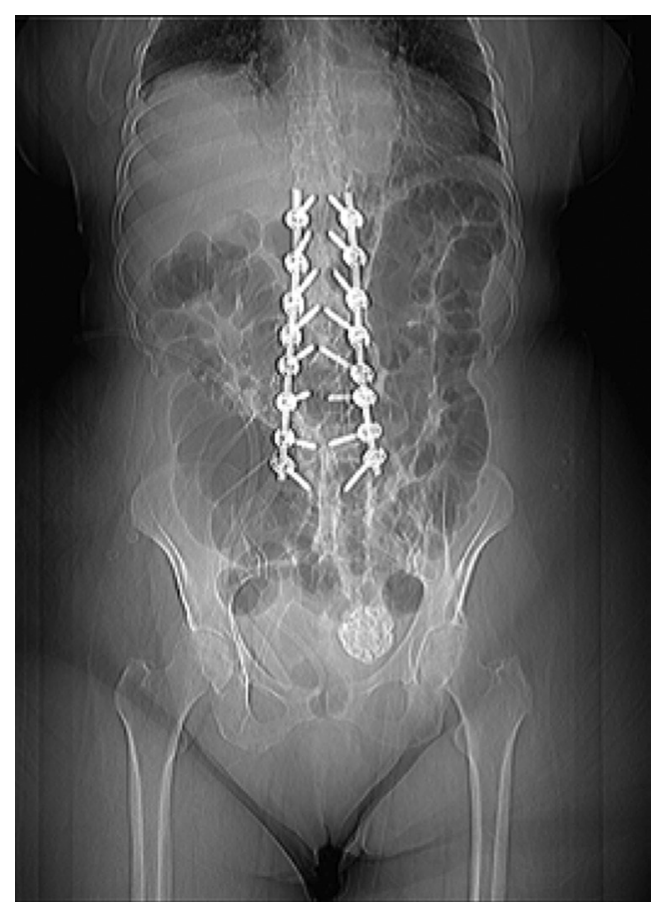

Figure 1. Postoperative radiograph (2nd day) showing dilatation of cecum

hemicolectomy, the burial of the distal transverse, and terminal ileostomy. It was necessary to introduce parenteral nutrition, and the patient presented a good outcome without recurrence of symptoms.

Patient No 3: A 41-year-male presented a traumatic bilateral facet dislocation of C5-C6 after diving into shallow water. The neurological status was classified as Frankel A. Anterior C5-C6 fixation was performed after open discectomy and reduction. The surgery was uneventful without complications. On the
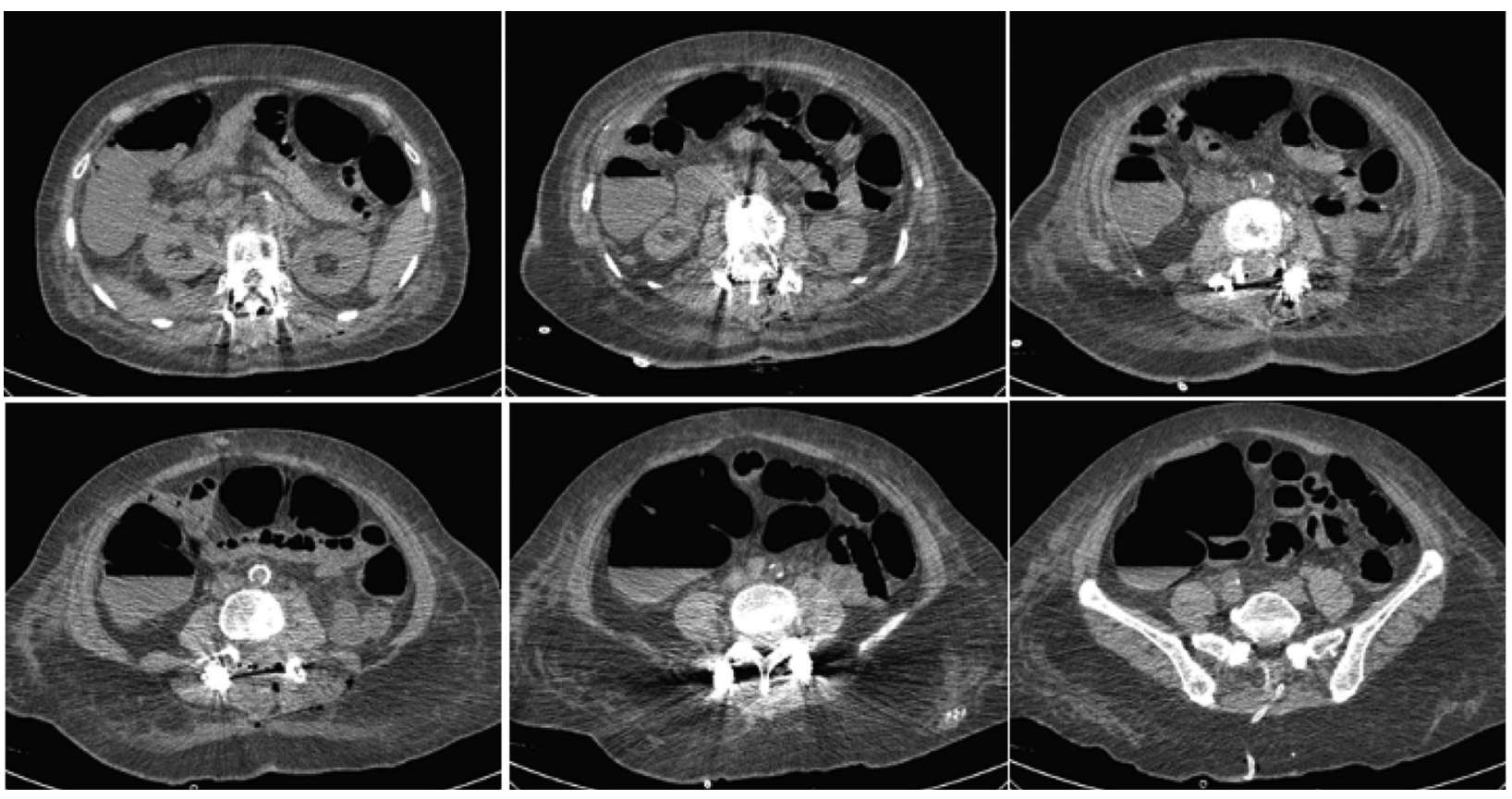

Figure 2. Postoperative CT showing dilated bowel of ascending colon without evidence of perforation 

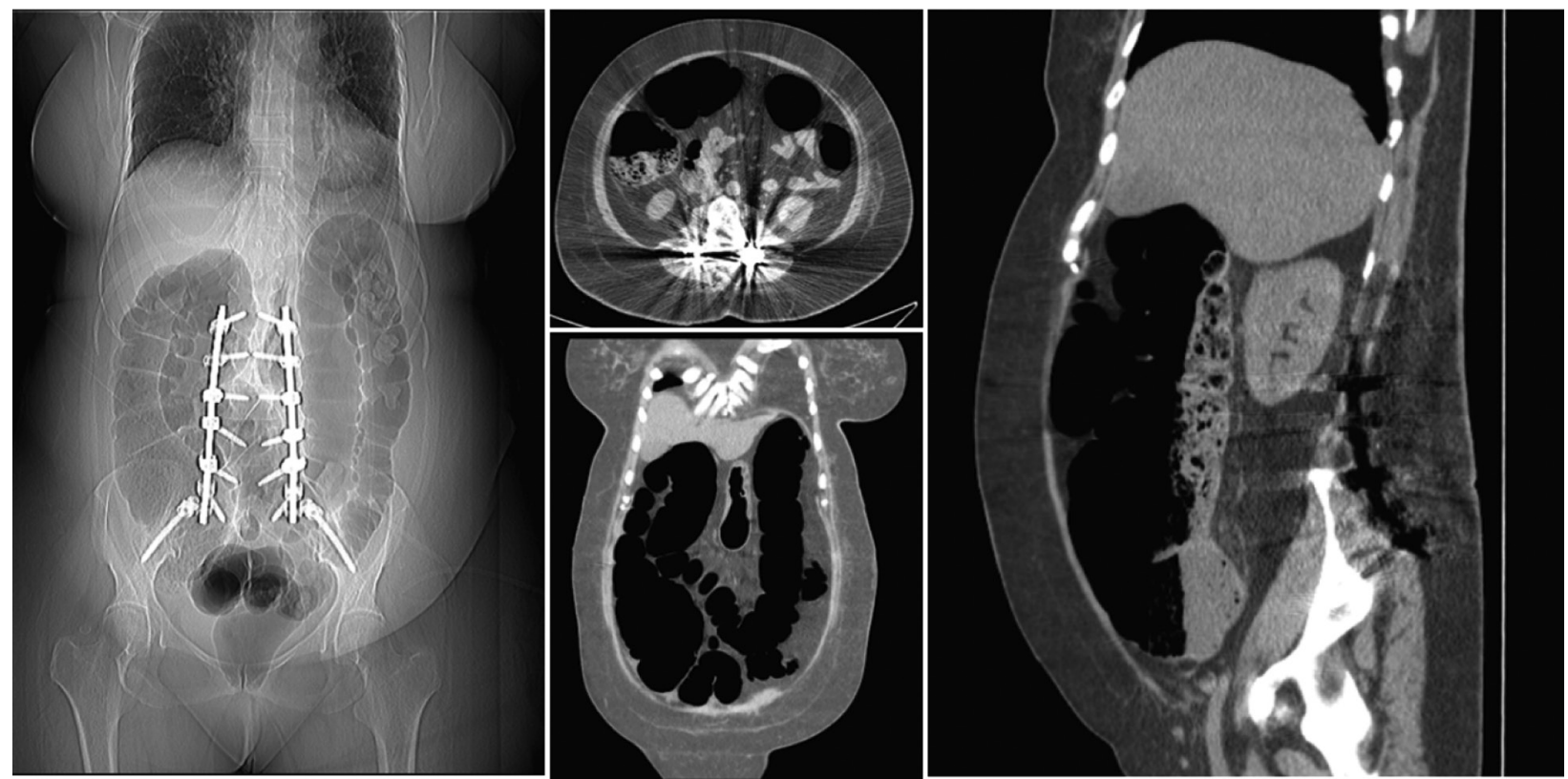

Figure 3. Plain radiography and CT showing dilated bowel without evidence of perforation

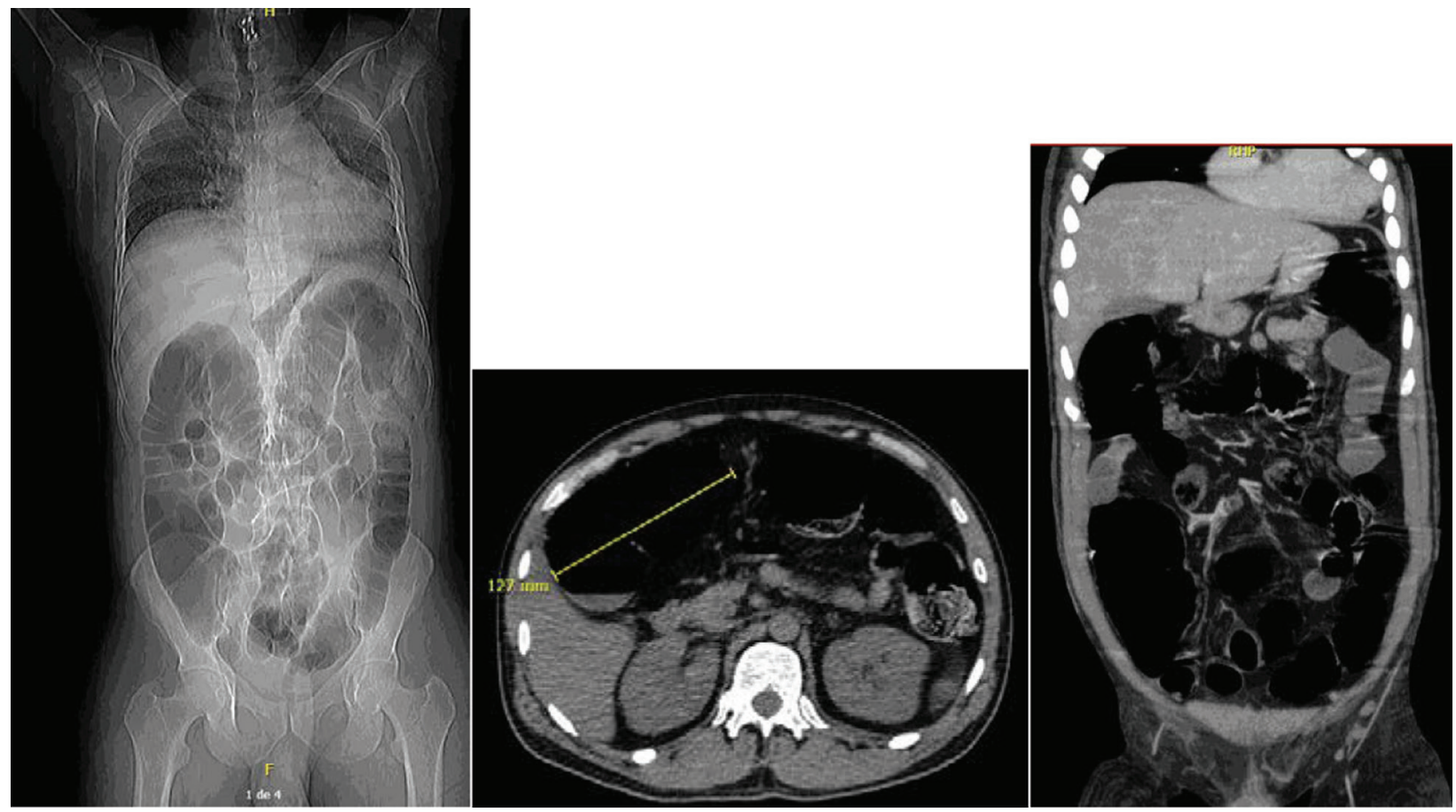

Figure 4. Plain radiography and CT showing dilated bowel without evidence of perforation

second postoperative day, the patient presented with diffuse abdominal pain, vomiting, and watery diarrhea. The abdominal plain radiography showed a dilated cecum and colon of $12 \mathrm{~cm}$, and CT showed dilated bowel without evidence of perforation (Figure 4). The Ogilvie syndrome was treated conservatively. The patient was kept nil per orally (NPO) with serial measurement of abdominal girth and serum electrolytes monitoring. A nasogastric tube was being inserted, and aggressive fluid and electrolyte resuscitation was initiated. Appropriate antibiotics were started infection is suspected. The abdominal distention and symptoms improved in 5 days.

\section{RESULTS}

One out of the three patients with Ogilvie syndrome died after clinical and respiratory complications besides the surgical treatment. Two patients had a complete recovery of the symptoms and signs of Ogilvie syndrome. One after surgical treatment and the other after conservative treatment. These two patients did 
not have any significant abdominal problems during the 2-year follow-up period.

\section{DISCUSSION}

The occurrence of Ogilvie syndrome in three patients within the scope of our practice shows that despite being rare, it should be included in the spectrum of postoperative complications of spinal surgery. Abdominal distention and pain are presented in $80 \%$ of the patients accompanied by nausea with or without vomiting in $60 \%$ of the patients. Ninety percent of the patients present tympanic abdomen and preserved bowels sounds (1).

So far, its pathology remains poorly understood. A multifactorial etiology is supported by the abundance of identified risk factors that lead to common or similar effects on the colon (1). An impairment of the autonomous system is observed with an imbalance between sympathetic and parasympathetic, an atonic distal colon, and a functional proximal obstruction (17).

The diagnosis of Ogilvie syndrome is mainly based on clinical symptoms and signs. Differential diagnosis should be considered in postoperative patients with abdominal pain and distention, although various intestinal diseases have to be ruled out before (18). It has been observed in patients with predisposed medical and surgical conditions. However, our three patients had no medical comorbidities. The use of medication such as opioids, calcium channel blockers, and anticholinergics can predispose to this syndrome (18). ACPO is more frequent in males $(1,5: 1)(20)$, although two out of the three patients were female.

The average age of presentation is approximately 60 years, and surgical patients are most likely to be diagnosed on postoperative days 3 to 5 , as we have observed in our patients (21).

The clinical picture of our patients characterized by unexplained abdominal pain and distention, nausea with or without vomiting, and plain abdominal radiographs or CT showing varying degrees of colonic dilation is the typical presentation of the disease. Abdominal distention and pain are observed in $80 \%$ of patients, and nausea with or without vomiting in $60 \%$. Diagnosis of ACPO is one of exclusion, and more common causes of functional or mechanical bowel dilation must be investigated $(2,3,22)$. In the presence of bowel ischemia, peritonitis, or perforation, ACPO is considered complicated, and it is directly related to the duration of the illness and increased cecal diameter (23).

The primary treatment is based on supportive care with close observation. Nasal gastric tube placement aids bowel decompression and nothing by month. Medication that impacts colonic mobility, such as opiates and anticholinergics, should be discontinued, and early pharmacological therapy has been encouraged. Neostigmine (short-acting anticholinesterase) has been recommended as a drug of choice. Invasive procedures and surgery are indicated for patients with severe disease (ischemia or perforation) or refractory to conservative treatment. The management of ACPO should be multi-professional, and the primary goal of the treatment is urgent bowel decompression (19).

The reported success rate of conservative treatment is $96 \%$, and early diagnosis and conservative treatment reduce the risk of surgical intervention (20, 21). However, we have not observed this picture in our patients. Besides the early diagnosis and conservative treatment according to the protocols (22), two patients underwent surgical intervention, and one of them died beside the surgical intervention. The general expected mortality of Ogilvie syndrome is $15 \%$ in uncomplicated patients and $30-40 \%$ in complicated ones. Cecal diameter and duration of illness are associated with the development of complications (21).

ACPO has been observed in $1-2 \%$ of spinal or othopaedic procedures. In the field of spinal surgery, Ogilvie syndrome was reported after posterior fixation for thoracolumbar fractures, lumbar disc, cervical discectomy, lumbar decompression for stenosis, correction of spinal deformity, and lumbar surgery $(8,9,18$, $23,24,25)$.

The general expected mortality of Ogilvie syndrome is $15 \%$ in uncomplicated patients and $30-40 \%$ in complicated ones. Cecal diameter and duration of illness are associated with the development of complications (21). Although rare, this syndrome should be included in the differential diagnosis of postoperative abdominal pain and distention.

\section{CONCLUSION}

Although Ogilvie syndrome is a rare disease, it should be suspected in patients that presented unexplained abdominal pain and distention in the postoperative period. Early diagnosis and conservative treatment can prevent bowel ischemia that leads to morbidity and mortality.

\section{Acknowledgment}

None.

Conflict of Interests: The authors declare that there are no conflicts of interest related to this article.

Funding: None

\section{Licensing}

This work is licensed under a Creative Commons Attribution 4.0 International (CC BY 4.0) License. 


\title{
Sažetak
}

\section{OGILVIJEV SINDROM NAKON OPERACIJE KIČMENOG STUBA}

\author{
Romulo Pedroza Pinheiro, ${ }^{1}$ Nascimento Ribeiro Leonardo, ${ }^{2}$ \\ Tavares Costa Rodrigo Herton, ${ }^{2}$ Aparecido Defino Luiz Helton ${ }^{2}$ \\ ${ }^{1}$ Department of Orthopaedic and Anesthesiology and Doctoral Student, \\ Ribeirão Preto Medical School, University of São Paulo, Brazil \\ ${ }^{2}$ Department of Orthopaedic and Anesthesiology, \\ Ribeirão Preto Medical School, University of São Paulo, Brazil
}

Cilj: Ogilvijev sindrom je retka bolest koju karakteriše akutni bol u stomaku i distenzija u odsustvu mehaničke opstrukcije. To je redak sindrom koji obično pogađa hospitalizovane pacijente zajedno sa teškom bolešću ili posle operacije. Nekoliko slučajeva je prijavljeno nakon operacije kičme.

Metode: Retrospektivni izveštaji Ogilvijevog sindroma kod tri pacijenta koji su podvrgnuti operaciji kičme (dve zadnje lumbalne instrumentalne fuzije i jedna prednja cervikalna fuzija). Hirurško lečenje je bilo potrebno kod dva pacijenta, a konzervativno lečenje kod jednog od tri pacijenta.

\section{REFERENCES}

1. Wells CI, O’Grady G, Bissett IP. Acute colonic pseudo-obstruction: A systematic review of aetiology and mechanisms. World J Gastroenterol. 2017; 23(30): 5634-44. doi: 10.3748/wjg.v23.i30.5634.

2. Ogilvie H. Large-intestine colic due to sympathetic deprivation; a new clinical syndrome. Br Med J. 1948; 2:671-3. doi: 10.1136/bmj.2.4579.671.

3. Vanek VW, Al-Salti M. Acute pseudo-obstruction of the colon (Ogilvie's syndrome). An analysis of 400 cases. Dis Colon Rectum. 1986; 29(3): 203-10. doi: 10.1007/BF02555027.

4. Ross SW, Oommen B, Wormer BA, Walters AL, Augenstein VA, Heniford BT, et al. Acute colonic pseudo-obstruction: defining the epidemiology, treatment, and adverse outcomes of Ogilvie's Syndrome. Am Surg. 2016; 82(2): 102-11. doi: 10.1177/000313481608200211.

5. Saha AK, Newman E, Giles M, Horgan K. Ogilvie's syndrome with caecal perforation after Caesarean section: a case report. J Med Case Rep. 2009; 3: 6177. doi: 10.4076/17521947-3-6177.

6. Guler A, Sahin MA, Atilgan K, Kurkluoglu M, Demirkilic U. A rare complication after coronary artery bypass graft surgery: Ogilvie's syndrome. Cardiovasc J Afr. 2011; 22(6): 335-7. doi: 10.5830/CVJA-2010-064.

7. Feldman RA, Karl RC. Diagnosis and treatment of Ogilvie's syndrome after lumbar spinal surgery. Report of three cases. J Neurosurg. 1992; 76(6): 1012-6. doi: 10.3171/ jns.1992.76.6.1012.

8. Krishnakumar R, Kuzhimattam MJ, Kumar G. Ogilvie's syndrome following posterior spinal instrumentation in thoracolumbar trauma. J Craniovertebr Junction Spine. 2015; 6(4): 179-82. doi: 10.4103/0974-8237.167866.

9. Caner H, Bavbek M, Albayrak A, Altinörs TC. Ogilvie's syndrome as a rare complication of lumbar disc sur-
Rezultati: Dva pacijenta su imala potpuni oporavak simptoma i znakova bolesti, a jedan je preminuo.

Zaključak: Ogilvijev sindrom je redak, ali ga treba uzeti u obzir u okviru diferencijalne dijagnoze kod pacijenata koji su bili podvrgnuti hirurškoj intervenciji, a imaju izražen abdominalni bol i distenziju.

\section{Nivo dokaza II; Retrospektivna studija.}

Ključne reči: Ogilvijev sindrom, pseudo-opstrukcija, spinalna fuzija.

gery. Can J Neurol Sci. 2000; 27(1): 77-8. doi: 10.1017/ s0317167100052033.

10. Cakir E, Baykal S, Usul H, Kuzeyli K, Cinel A. Ogilvie's syndrome after cervical discectomy. Clin Neurol Neurosurg. 2001; 103(4): 232-3. doi: 10.1016/s0303-8467(01)00167-6.

11. Nelson JD, Urban JA, Salsbury TL, Lowry JK, Garvin KL. Acute colonic pseudo-obstruction (Ogilvie syndrome) after arthroplasty in the lower extremity. J Bone Joint Surg Am. 2006; 88(3): 604-10. doi: 10.2106/JBJS.D.02864.

12. Reverdy D, Gebhart M, Kothonidis K, Gallez J, De Becker D, Liberale G. Pseudo-colonic obstruction after lumbar spine surgery: A case report. Acta Orthop Belg. 2006; 72(6): 769-7.

13. Shi XZ, Lin YM, Powell DW, Sarna SK. Pathophysiology of motility dysfunction in bowel obstruction: role of stretch-induced COX-2. Am J Physiol Gastrointest Liver Physiol. 2011; 300(1): G99-G108. doi: 10.1152/ajpgi.00379.2010.

14. Pereira P, Djeudji F, Leduc P, Fanget F, Barth X. Ogilvie's syndrome-acute colonic pseudo-obstruction. J Visc Surg. 2015; 152(2): 99-105. doi: 10.1016/j.jviscsurg.2015.02.004.

15. Nanni G, Garbini A, Luchetti P, Nanni G, Ronconi P, Castagneto M. Ogilvie's syndrome (acute colonic pseudo-obstruction): a review of the literature (October 1948 to March $1980)$ and report of four additional cases. Dis Colon Rectum. 1982; 25(2): 157-66. doi: 10.1007/BF02553265.

16. Saunders MD, Kimmey MB. Colonic pseudo-obstruction: the dilated colon in the ICU. Semin Gastrointest Dis. 2003; 14(1): 20-7.

17. Bardsley D. Pseudo-obstruction of the large bowel. $\mathrm{Br}$ J Surg. 1974; 61(12): 963-9. doi: 10.1002/bjs.1800611210.

18. Feldman RA, Karl RC. Diagnosis and treatment of Ogilvie's syndrome after lumbar spinal surgery. Report of three cases. J Neurosurg. 1992; 76(6): 1012-6. doi: 10.3171/ jns.1992.76.6.1012. 
19. Costa G, Ruscelli P, Balducci G, Buccoliero F, Lorenzon L, Frezza B, et al. Clinical strategies for the management of intestinal obstruction and pseudo-obstruction. A Delphi Consensus study of SICUT (Società Italiana di Chirurgia d'Urgenza e del Trauma). Ann Ital Chir. 2016; 87: 105-17.

20. Machado Teles Filho AA, da Mota BA, Silva MSR, Santos DS, de Menezes JWR, Aragão JA. Síndrome de Ogilvie: Uma revisão de literatura. REAC [Internet]. 23dez.2019 [citado 1jun.2021];2:e1940

21. Conner S, Nassereddin A, Mitchell C. Ogilvie Syndrome. In: StatPearls. Treasure Island (FL): StatPearls Publishing; July 2, 2020.
22. Maloney N, Vargas HD. Acute intestinal pseudo-obstruction (Ogilvie's syndrome) Clin Colon Rectal Surg. 2005; 18(2): 96-101. doi: 10.1055/s-2005-870890.

23. Shahait AD, Mostafa G. Ogilvie's Syndrome or Colonic Pseudo-Obstruction. Am Surg. 2018; 84(1): e38-e39.

24. Lee SK, Lee SH, Park BM, Yang BS, Kim JH, Lee HM. Ogilvie's Syndrome after Lumbar Spinal Surgery. J Korean Soc Spine Surg. 2019; 26(2): 63-7.doi: 10.4184/jkss.2019.26.2.63.

25. Tsirikos AI, Sud A. Ogilvie's syndrome following posterior spinal arthrodesis for scoliosis. Indian J Orthop. 2013; 47(4): 408-12. doi: 10.4103/0019-5413.114934.

\section{Correspondence to/Autor za korespondenciju}

Romulo Pedroza Pinheiro

Department of Orthopaedic and Anesthesiology and Doctoral Student,

Ribeirão Preto Medical School, University of São Paulo, Brazil

Av. Bandeirantes 3900, Monte Alegre, 14049900, Ribeirão Preto, SP-Brazil

Phones: (16) 3602-2513, (85) 99610-3964

E-mail: romulopinheiro@usp

How to cite this article. Pinheiro PR, Nascimento RL, Tavares CRH, Aparecido DLH. Ogilvie syndrome following spinal surgery. Sanamed.2021;16(3): 215-220 